\title{
Grief on the Road: A Proposal for the Prevention of Road Traffic Injuries
}

\author{
Maria Vieira de Lima Saintrain ${ }^{1}$, Christian Marcel Prudent Saintrain ${ }^{2}$ \\ ${ }^{* 1}$ DDS, Msc, PhD, Pos-doc in Public Health, Professor of the Public Health Masters Program, \\ University of Fortaleza - UNIFOR, Brazil. \\ Av Washington Soares, Edson Queiroz, Fortaleza Ceara. \\ ${ }^{2}$ Electric-electronic Engineering Technician. École Téchnique de Morlanwelz, Belgium. \\ Rua Irmâ Simas, 100 apto 201, Varjota - Fortaleza Ceara, \\ ${ }^{1}$ mvlsaintrain@yahoo.com.br, ${ }^{2}$ christiansaintrain@hotmail.com
}

\begin{abstract}
:
Introduction: Road traffic injuries are still a major public health problem worldwide.

Objective: To develop soft educational technologies to promote in a simple and clear way the prevention of road traffic injuries.

Methods: Field research that uses original photographs taken in the year 2016 on the road between the cities of Fortaleza and Barbalha in the state of Ceará - Northeastern Brazil. The researchers of the present study nurtured by scientific curiosity - took pictures of small roadside memorials built by people in memory of their loved ones who were victims of road traffic injuries and violence along the road.
\end{abstract}

Results: On the road from Fortaleza to Barbalha over 200 roadside memorials highlighted what has been called "GRIEF ON THE ROAD". The photographic material, which symbolized the tragedies, was used to develop soft technologies in the form of warning signs in order to raise awareness about the risks and recklessness in driving motor vehicles.

Conclusion: The evidence of lives cut short by road traffic injuries and the warning signs developed from the photos of the reality that is notoriously exposed along the road can help public policy-makers to raise awareness of vehicle drivers about the human responsibility and sensibility concerning the dangers of noncompliance with traffic laws.

Keywords: Traffic accidents; Death; Grief; Road.

\section{INTRODUCTION}

Road traffic injuries have been recognized by the United Nations and its Member States as a major challenge to the achievement of health and development goals. The epidemiological analysis shows that in 2004 these injuries appeared as the 9th leading cause of death and are expected to rise to become the 5th in 2030 [1].

In Brazil, the document titled "Retrato da segurança viária" (A portrait of road safety) (2014) highlights the road safety situation in Brazil as a complex problem characterized by a steady growth in the number of deaths in the last 14 years. In 2012, there were 45,700 fatal injuries - one death every 12 minutes - and 177,400 non-fatal injuries. Noteworthy, the document shows that five Brazilian states are at the top of the list with the highest absolute number of injuries: São Paulo $(39,976)$; Minas Gerais $(18,692)$, Ceará $(11,132)$, Rio de Janeiro $(11,107)$ and Paraná $(10,709)$. The states with the lowest number of injuries are Tocantins (961), Acre (849) and Amapá (832).

Although the state of Ceará ranks 3rd in absolute number of injuries $(11,132)$, it is not among the five states with the highest number of deaths. However, two cities located in the state are among the three Brazilian cities with the worst road traffic death rates per 100 thousand inhabitants: Barbalha, ranking 2nd (194.4) and Sobral, ranking 3rd (108.7), behind only the city of Presidente Dutra located in the state of Maranhão (237) [2]. 
According to the World Health Organization [3], of all the systems with which people have to deal every day, road traffic systems are the most complex and the most dangerous.

At this juncture, it is clear that road traffic injuries constitute a major public health problem worldwide.

In the state of Ceará - Northeastern Brazil, people have the habit of identifying the sites of fatal road traffic injuries along the roads. They usually build small roadside memorials in memory of their loved ones that also serve as a reminder and warning of the dangers of driving.

Given the above, the present study aimed to develop soft educational technologies to promote in a simple and clear way the prevention of road traffic injuries.

\section{METHODS}

This is a field research that uses original photographs taken in the year 2016 on the road between the cities of Fortaleza and Barbalha in the state of Ceará - Northeastern Brazil.

The city of Barbalha has a total area of $569.508 \mathrm{~km}^{2}$ and 55,323 inhabitants; it is $575 \mathrm{~km}$ far from the city of Fortaleza [4].

The city provides visitors with valuable natural attractions such as the Araripe National Forest. It also has an ecosite (Araripe Geopark) that is a strategy for the protection of natural resources adopted by UNESCO in order to reconcile the conservation of natural heritage and the local sustainable development (Silveira et al., 2012)[5] as well as to encourage regional tourism.

Given the fact that Barbalha ranks 2nd in road traffic death rates in Brazil, the researchers of the present study - nurtured by scientific curiosity - decided to travel the road between the city of Fortaleza (capital of the state of Ceará) and the aforementioned city. During the travel, the researchers took pictures of small roadside memorials built by people in memory of their loved ones who were victims of road traffic injuries along the road.

The photographic material, which symbolized the tragedies, was used to develop soft technologies in the form of warning signs in order to raise awareness about the risks and recklessness in driving motor vehicles.

\section{RESULTS}

Over 200 roadside memorials were found on the road from Fortaleza to Barbalha. In order to represent what has been called "GRIEF ON THE ROAD" in the present paper, 12 photos were selected and transformed into soft technology, which contributed to the development of warning traffic signs to prevent injuries,

Educational technology was produced from the photographs and different warning signs portraying the reality found were developed.
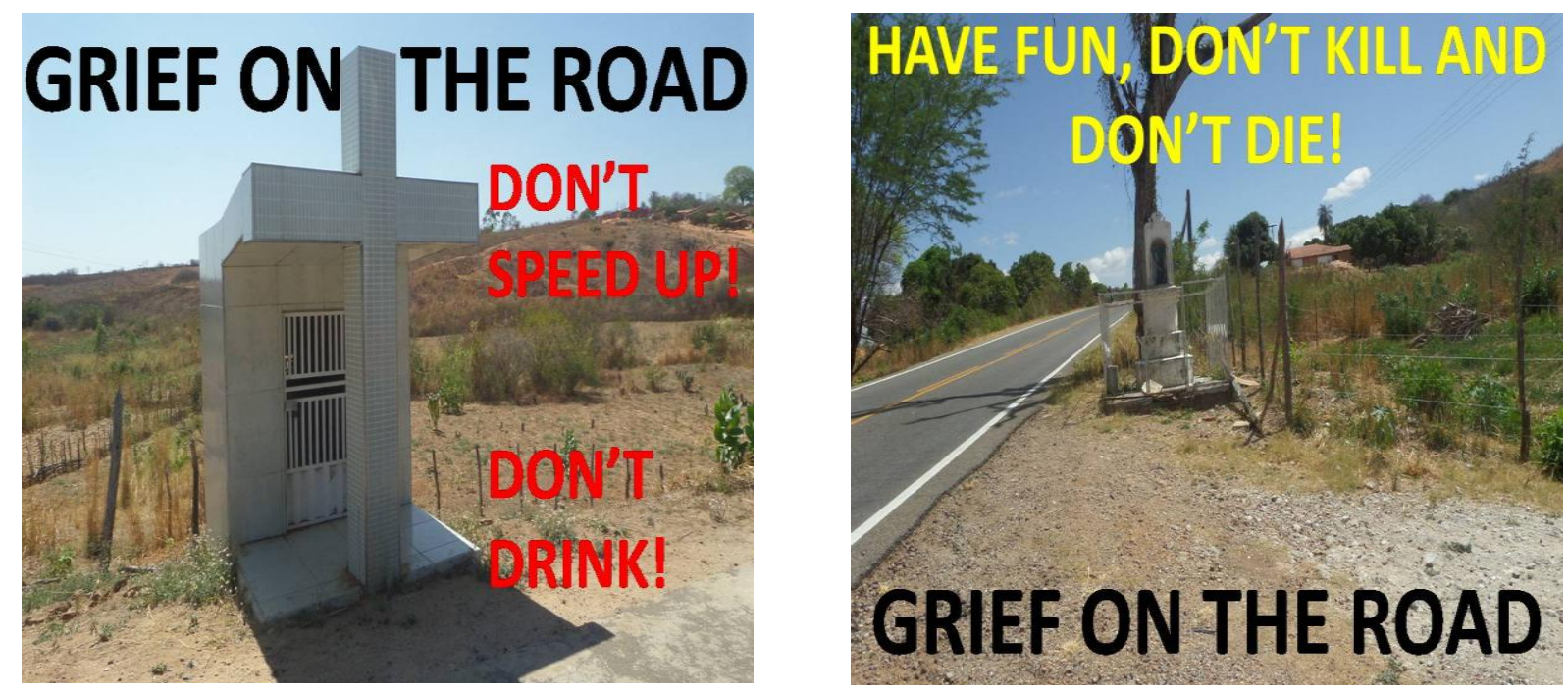

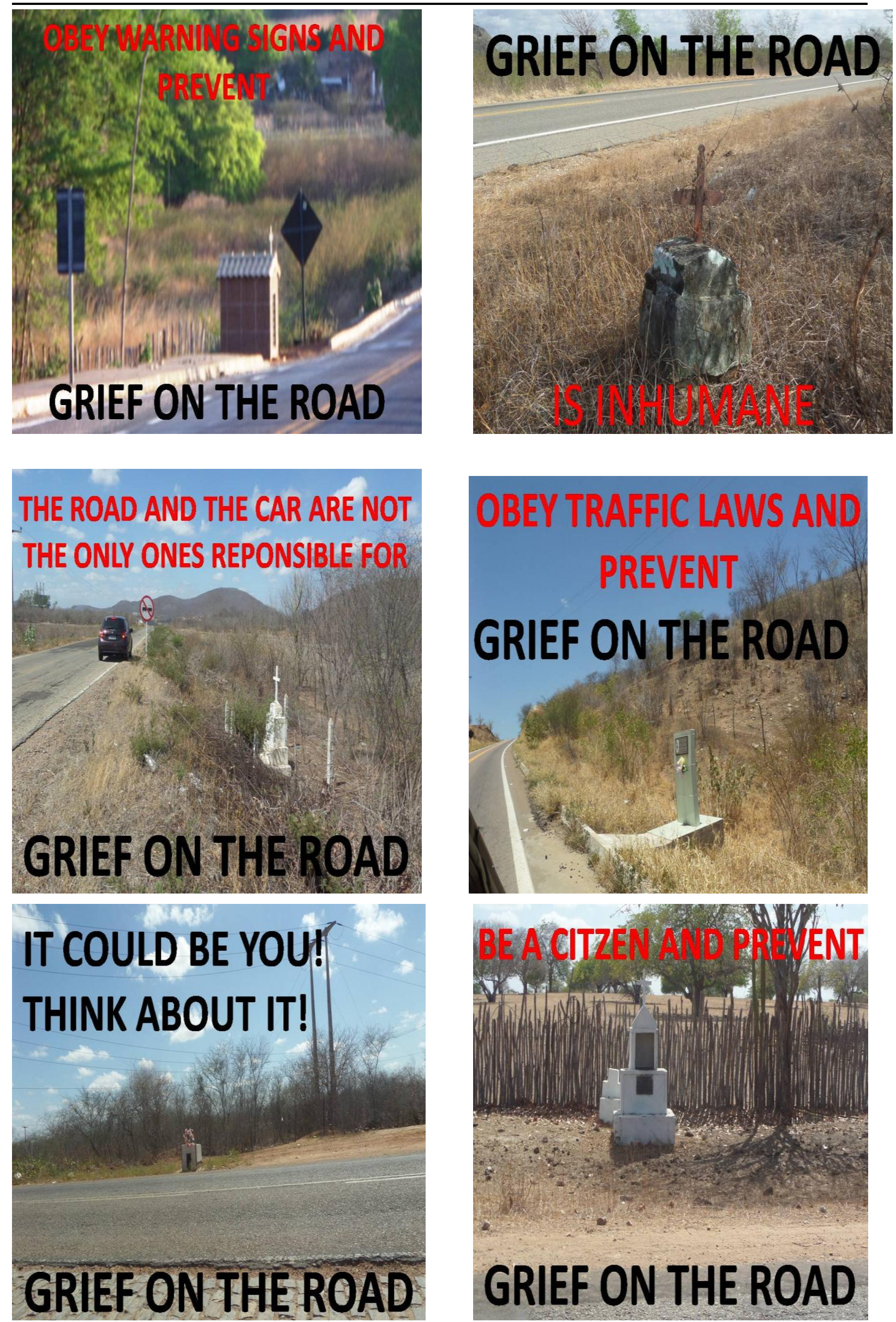

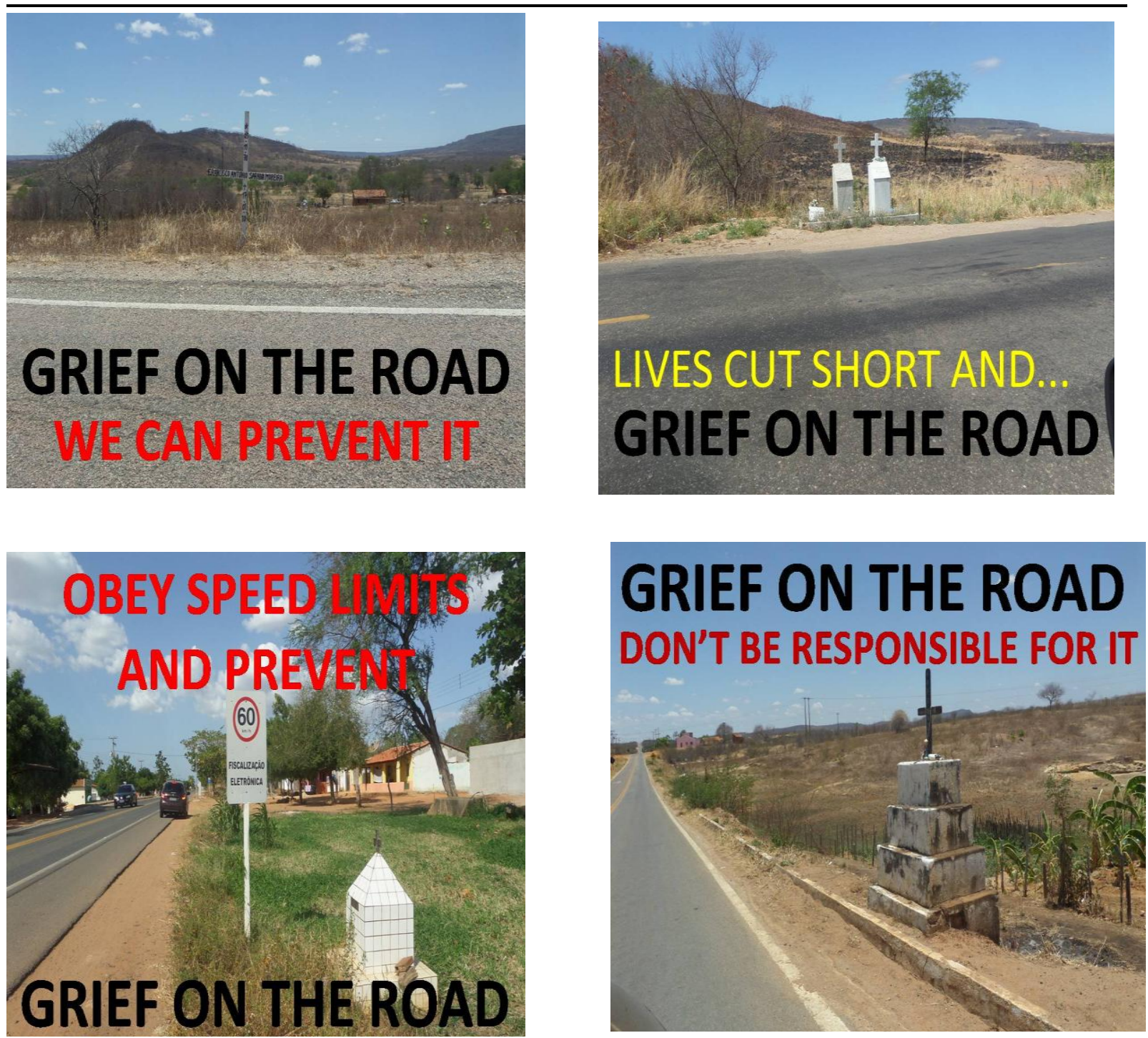

\section{DisCUSSION}

The present research stands out as the authors have been inspired by the lesson from Albert SzentGyorgyi (1893 - 1986) who said that "Research is to see what everybody else has seen, and think what nobody has thought" [6].

In fact, considering such a delicate and embarrassing issue, it was necessary to look for something that could help meet the human responsibility and sensibility of those who saw, but did not think.

All the warning instruments produced from the photographs permeate the grief of families, relatives, friends and society in general regarding road traffic injuries.

Every day, thousands of people are killed and injured on our roads. Many men, women or children walking, biking or riding to school or work, playing in the streets or setting out long trips, will never return home, leaving behind shattered families and communities [7].

According to the WHO, $49 \%$ of all road traffic deaths are among pedestrians (22\%), cyclists (4\%) and motorcyclists (23\%), with 3 out of 4 road deaths among men; additionally, low-income countries have the highest road traffic death rates (WHO, 2015). \{8]

Statistics show that national and international laws to prevent road traffic injuries do not appear to halt or reduce the rates of these injuries.

Given that, the United Nations General Assembly officially proclaimed, in March 2010, the Decade of Action for Road Safety 2011-2020. This document provides key information about the decade and the role of WHO to save millions of lives [1]. 
The Brazilian Traffic Code (BTC) is modernly derived from the innovative principles of the Federal Constitution; however, its effectiveness depends on the commitment of all. Its regulation, as a means to develop safe behavior in traffic or claim responsibility from all actors - public and private - for the safety of the roads and vehicles, requires attention to the application of its provisions [9].

As a result of effective traffic laws and programs, the European Union had a decrease in fatality rate among its Member States. In 2010, there were 63 deaths per million inhabitants and in 2014 the rate decreased to 51 deaths per million inhabitants. Traffic programs include education, enforcement, vehicle safety and road infrastructure actions [10].

However, only in the last two decades have road traffic injuries been recognized as a public health problem. The discussion over injuries, violence and death by external causes highlights the drinkdriving combination as a problem that requires specific public policies [11].

Importantly, not only road users, but also society in general, including the media with its high power of communication and information distribution, exert strong influence on the development of public policies for the management of road safety. Thus, it is the duty of every citizen to fight for this safety, which is a major public health issue [2].

In this context, it is understood that raising awareness of road traffic injuries requires the confrontation of road users with such reality that is notoriously exposed and observed along the way.

A limitation of the present research is the fact that it focused empirically on a single road. However, as it was carried out in order to provide an overview of the impact that measures the severity of road traffic injuries and violence, it contributed to the development of soft technology for the promotion of care and prevention of accidents, contributing to public health policies. In addition, informal reports from people living near the memorials confirm that they are representative of road traffic accidents. Further studies should strengthen research in this field.

\section{Conclusion}

The risky experience of gathering evidence of lives cut short by road traffic injuries highlights the need for greater rigor in the development and application of road safety policies.

It is understood that the warning signs produced from the photographed reality that is notoriously exposed along the road can help public policy-makers to raise awareness of vehicle drivers about the human responsibility and sensibility concerning the dangers of non-compliance with traffic laws.

CONTRIBUTORS: Santrain MVL and Saintrain CMP devised the research project, performed data collection, literature review and review of all versions.

\section{REFERENCES}

[1] WHO. World Health Organization. Decade of Action for Road Safety 2011-2020 Saving millions of lives. 2011. Available from http://who.int/violence_injury_prevention/ publications/ road_traffic/saving_millions_lives_en.pdf. Cited 20 April 2016.

[2] Brasil. Retrato da segurança viária 2014. 105p. Available from http://iris.onsv.org.br/ portaldados/downloads/retrato2014.pdf . Cited 15 April 2016.

[3] WHO. World Health Organization Report on road traffic injury prevention: summary. WHO Library Cataloguing-in-Publication Data. 2004. Available from http://www.who.int/ violence_ injury_prevention/publications/road_traffic/world_report/summary_en_rev.pdf . Cited 27 May 2016.

[4] IBGE, Censo Demográfico 2010. Available from http://www.censo2010.ibge.gov.br/ sinopse/webservice/frm_urb_rur.php?codigo=230190. Cited 10 April 2016.

[5] Silveira AC, Silva AC, Cabral NRAJ, Schiavetti A. Análise de efetividade de manejo do Geopark Araripe - Estado do Ceará. São Paulo, UNESP, Geociências 2012; 31(1):117-128.

[6] Szeged International conference, University of Szeged. Szent-Györgyi 75 - Conference in Szeged 2012. Available from http://szegedmed.hu/pdf/Conference_summary.pdf. Cited 27 April 2016.

[7] Lee Jong-wook, Wolfensohn JD. World report on road traffic injury prevention: summary. World Health Organization, Geneva 2004. 
[8] HWO. Global status reporto $\mathrm{n}$ Road safety 2015. Available from: http://www.who.int/ violence_injury_prevention/road_safety_status/2015/magnitude_A4_web.pdf?ua=1. Cited 20 May 2016.

[9] Brasil, Código de Trânsito Brasileiro. Código de Trânsito Brasileiro: instituído pela Lei no 9.503 , de 23-9-97 - $3^{a}$ edição - Brasília: DENATRAN, 2008. Available from: http:// www. denatran. gov.br/publicacoes/download/ctb.pdf. Cited 28 May 2016

[10] European Commission - EC. Road safety in the European Union: trends, statistics and main challenges. Published by: European Commission, Mobility and Transport DG, BE-1049 Brussels. 2015. Available from http://ec.europa.eu/transport/road_safety/ pdf/ vademecum_2015. pdf. Cited 12 May 2016.

[11] Almeida, ND. Os acidentes e mortes no trânsito causados pelo consumo de álcool: um problema de saúde pública. R. Dir. Sanit 2014; 15 n.2, p.108-125. 